\title{
Archaeology of Marronage in the Caribbean Antilles
}

\author{
Arqueologia da marronagem nas Antilhas do Caribe
}

Theresa Ann Singleton*

SINGLETON, T.A. Archaeology of Marronage in the Caribbean Antilles R. Museu Arq. Etn., 35: 01-13, 2020.

\begin{abstract}
The archaeological study of maroons in the Caribbean Antilles presents both opportunities and challenges. On small islands, runaways had few places where they could seek refuge from slavery and elude capture for long periods of time. Consequently, such sites were occupied briefly and have been difficult to locate and identify. The Greater Antilles (Cuba, Jamaica, Hispaniola, and Puerto Rico) had both short-term refuge sites and long-term settlements comparable to quilombos. Archaeologists have been most successful in their investigations of maroons in Cuba and Jamaica. In Hispaniola, where I am working at the moment, only a few cave sites and one presumed maniel (local term for a long-term maroon settlement) have been studied. In this paper, I provide an overview of the archaeological study of maroons on the Caribbean Islands and my preliminary research to locate El Maniel de Ocoa, a major settlement of slave runaways for over a hundred years during the 1500 s-1660s.
\end{abstract}

Keywords: Slavage, Marronage, Historical Archaeology, Resistance, Caribbean Archaeology

\section{Introduction}

The Caribbean is a very diverse, I complex region that is variously defined from geographical, cultural, historical, or political perspectives. It encompasses the islands and the associated mainland areas that span from the Florida Keys to northern South America, even though the Florida

" Professor at the Department of Anthropology, Syracuse University, USA. >tasingle@syr.edu>
Keys, Bahamas, Barbados, Guyana, Suriname, and French Guiana have no shorelines on the Caribbean Sea. On the other hand, Mexico and all the countries of Central America border the western edge of the Caribbean Sea, but are not always included or thought of as part of the Caribbean region (FIGURE 1) Furthermore, the diverse geographies, histories, peoples, languages, and political regimes constrain the comprehensive treatment of the region as whole, making any synthesis of Caribbean slavery and marronage a formidable task. 


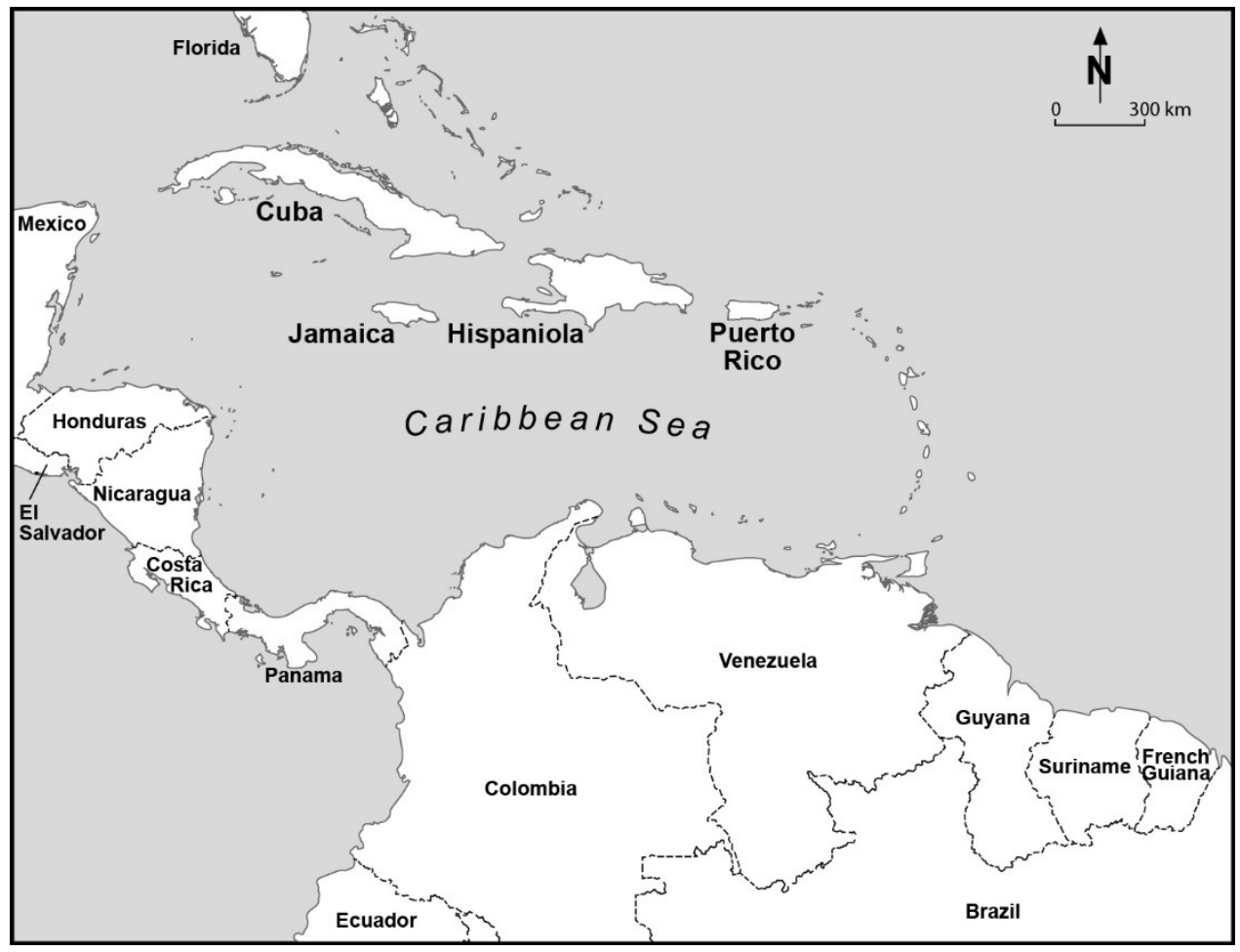

Fig. 1. Map of the Caribbean Region.

Source: Drawn by Syracuse University Cartographic Laboratory.

Marronage refers to the processes of slave flight, self-liberation, and survival. It occurred throughout the Caribbean, but long-term settlements appear to have been confined to the larger islands (Cuba, Jamaica, Hispaniola, Puerto Rico). Of the larger islands, only Jamaica has present-day maroon communities comparable to Brazilian quilombos that are descendant from slave runaways of the seventeenth and eighteenth centuries. In this paper, I examine previous and ongoing archaeological research as well as the prospects for and challenges to undertaking maroon archaeology on Caribbean islands. The size, location, and, most significantly, the physical geography of the Caribbean islands played major roles in the forms of marronage that developed on any particular island. I briefly examine marronage in six case studies: (1) Barbados; (2) English Leeward Islands of Monserrat, Antigua, and St. Kitts, Nevis, and Barbuda; (3) St. Croix, US Virgin Islands; (4) Jamaica; (5) Cuba; and (6) Hispaniola in the present-day nation of the
Dominican Republic, to provide an overview of maroon archaeology in the Caribbean as well as a context for an ongoing project in the Dominican Republic on slave runaways.

\section{Defining marronage}

The conventional categories used to define maroons are: petite marronage - short-term for flight from slavery by an individual or small group of individuals with temporary goals and the desire of returning to the plantation; and grand marronage - large-scale slave flight that resulted in the formation of long-term, independent communities with no intention of ever returning to the plantation. Over the years, these definitions based on the duration, motivation, numbers of individuals, or other factors have been debated, refined, and more recently, discarded by some scholars (Diouf 2014; Ritz 2016). These traditional definitions are often 
problematical for archaeological research as it is very difficult, if not impossible, to determine solely from archaeological resources different variables such as the numbers of runaways, their motivations, or even for how long they occupied the sites attributed to them. This is especially true for the temporary character of petite marronage which yield few, if any, artifacts. It is also difficult to distinguish a temporary refuge for runaways from sites used for other purposes, such as a social or ritual space, that may be unrelated to marronage but nonetheless may be associated with other forms of slave resistance, sometimes referred to as cultural resistance - the use of art, religion, or other traditional practices to challenge oppressive social systems. It may also be difficult to determine, if the archaeological context presumably related to petite marronage indicate days, weeks, months, or even a longer period time.

Maroons fled to places where they could elude capture for as long as possible - in thick forests, swamplands, mountains, caves and overhangs, and other localities that offered seclusion and were hard to access "because of difficulty of the terrain" (Diouf 2014: 4). Due to the strong relationships between marronage and geography, historian Svlviane Diouf offers definitions of marronage based on where runaways chose to seek refuge from slavery: (1) Borderland maroons lived on the fringes of plantations; (2) Hinterland maroons lived further away in inaccessible locations where seclusion was more critical than distance. In her study of southern United States, she found that hinterland maroons sometimes lived only $8-10 \mathrm{~km}$ from the plantation the runaways fled.

These two categories, however, should not be thought of as two types of marronage, but as parts of the larger landscapes runaways occupied. Borderlands and hinterlands together formed the maroon landscape - a vast area connected by secret paths, trails, waterways navigated at night, and temporary hiding places (Diouf 2014: 9). Runaways traveled through this landscape often moving back and forth from borderland to hinterland. By framing the archaeological study of maroons as landscapes where various forms of slave flight took place, some of which can potentially be rediscovered through archaeology, we avoid some of the archaeological problems associated with the terms petit and grand marronage. More significantly, the concept of maroon landscape provides a spatial framework that can facilitate archaeological investigations.

\section{Case studies}

\section{Barbados}

Founded in 1627, Barbados was the first English colony to develop sugar production based on African Labor (Handler 1997: 183). A small, relatively flat island of only 34 kilometers (21 miles) in length and up to $23 \mathrm{~km}$ (14 mi) in width, covering an area of $432 \mathrm{~km}^{2}$ (167 sq mi). Sugar culture transformed Barbados within a decade from a colony with landholdings of varied sizes that included a white non-slaveholding class, mixed agriculture, and a predominant workforce of white indentured servants to a colony of sugar plantations, controlled by an elite planter class, and worked by black enslaved laborers. Between 1645 and 1650, the African population doubled, while the white indentured population decreased significantly.

Barbados' small size and the lack of mountains, dense forests, or extensive cave systems presented obstacles for the formation of long-term maroon communities (Newman 2017: 51). In the early decades of colonization, marronage in Barbados involved small bands of runaways that lived in the island's forested interior areas and subsisted on raiding farms and plantations. By the 1670 s, as sugar cultivation expanded, the island became deforested. Deforestation not only changed the island's environment, but the nature of marronage (Handler 1997: 187). Slaves continued to run away, but with the clearing of the forest, they found other places to seek refuge, including caves scattered about the island, ditches, and ravines. Some runaways headed to town where they assumed the identities of "Free Blacks," until their former 
identities as slave runaways were revealed, which subjected them to recapture and severe punishment. Other maroons escaped the island by boat - a widespread practice in the Caribbean referred as "maritime marronage." The frequency of maritime marronage may explain why few maroon sites have been identified on islands where large numbers of slave runaways were reported. In the seventeenth century, slave runaways who fled Barbados most likely went to St. Vincent, which was about $150 \mathrm{~km}$ from Barbados and not yet colonized; it remained unplanted until the eighteenth century. African runaways from Barbados and other islands intermarried the indigenous people of St. Vincent and became known as the Black Carib or the Garifuna.

Archaeologists have not intentionally studied maroons in Barbados, but discovered caves containing archaeological materials presumably associated with runaways while excavating nearby plantations (Armstrong 2015; Smith 2008: 112-132). These artifact assemblages usually include arrays of metal objects (tools, iron pots), bottles, and a few clothing and adornment items like buttons and beads. Archaeological investigation of the Barbadian caves has generated two possible interpretations for its use: first, these sites provided temporary refuges for slave runaways on the borderlands of plantations; second, they were used as secret gathering places for the enslaved where the primary activity may have been drinking alcoholic beverages based on the large numbers of bottles and other beverage containers recovered from these caves (Smith 2008: 124-132). Matthew Reilly (2019: 132) offers another plausible interpretation for the large number of bottles found inside the cave, suggesting they were placed there to collect water from dripstones. Barbados as well as many of the small Caribbean islands lack sufficient sources of freshwater. The caves were possibly used for both temporary runaways and as social/ritual spaces. The bottles most likely initially contained alcoholic beverages, but were probably reused for water collection, storage and consumption (Reilly 2019: 134).

\section{English Leeward Islands}

The Leeward Islands refers to the group of islands lying east of Puerto Rico and continuing south to where the Windward Islands begin with the island of Martinique (FIGURE 2). The islands of Antigua, Montserrat, Nevis and Saint Kitts were among the largest and most important sugar producers of the British Leeward Islands (FIGURE 2). The close proximity of these islands to each other not only facilitated regional trade (Dator 2015: 339) but together may have formed a maroon landscape. Montserrat is $48 \mathrm{~km}$ from Nevis/St. Kitts, Nevis/St. Kitts is $68 \mathrm{~km}$ from Antigua, and Antigua is $38 \mathrm{~km}$ from Montserrat. Like Barbados, the small size and deforestation from the plantation agriculture limited the amount of hiding spaces for runaways on these islands. But unlike Barbados, many of the Leeward Islands contain steep volcanic peaks that were unsuitable for plantation agriculture but provided amenable terrain for the temporary refuge of runaways. Frank, a man initially enslaved in Montserrat, fled to these islands eventually making his way to Jamaica, 1,400 kilometers away. Frank's travel itinerary spans from 1700-1730, and is well documented in correspondence between his absentee owner and plantation manager and colonial government records. Frank was an exceptional case, but James Dator (2015), who traced Frank's travels, indicates there were many other slave runaways who fled to nearby islands on a regular basis often secretly taking passage on ships docked on these islands. 


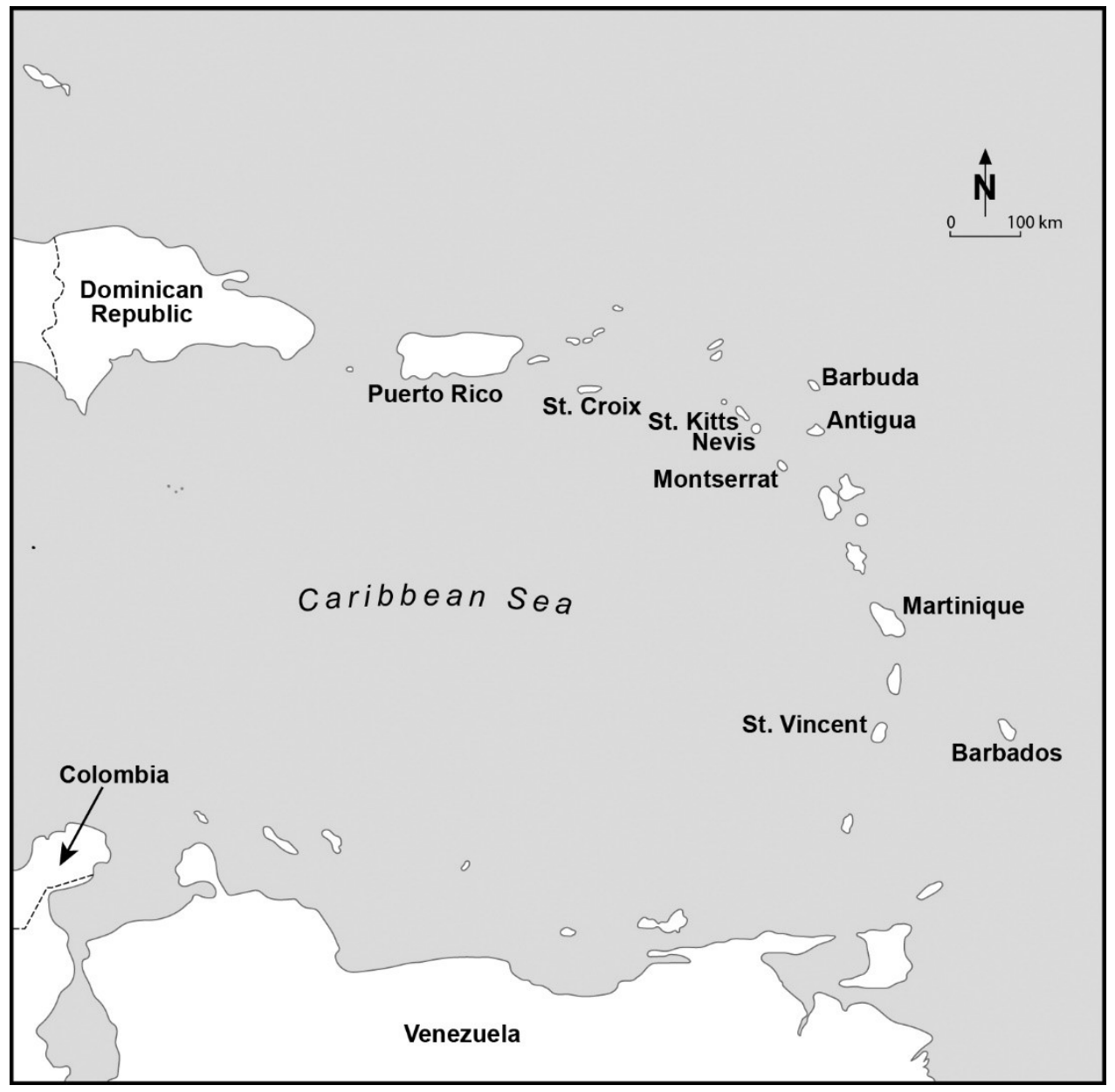

Fig. 2. Leeward Islands from East of Puerto Rico to the Windward Island of Martinique.

Source: Drawn by Syracuse University Cartographic Laboratory.

No archaeological studies of slave runaways have been reported from the four British Leeward Islands, but a potential runaway site has been reported on the nearby island of Barbuda. It was a cave site containing a small amount of artifacts: a few bottles, white clay pipes, gun flints of the late eighteenth and early nineteenth centuries, and curiously, a significant number of bones from a cat (other animal remains recovered include: cattle, pig, sheep/goat, turtle). The site is interpreted as a ritual space, and the authors posit that the cat remains suggest the Afro-Caribbean spiritual and healing tradition known as Obeah. Obeah developed among West Africans in the
Caribbean, and cat remains have been recovered in Obeah contexts from other Caribbean islands in the region (Perdikaris et al. 2013: 5-6).

\section{St. Croix, US Virgin Islands}

The final small island is St. Croix, one of the three US Virgin Islands. These islands were colonies of Denmark from the seventeenth to early twentieth centuries until the United States purchased them in 1917. Despite its small size of only 218 sq. km., documental sources indicate that small groups of runaways developed a continuous presence in the northwestern 
corner of the island, in areas known as Maroon Ridge and Maroon Hole. Maroon Ridge remains significant for St. Croix residents to this day and remains a rugged and remote area; Maroon Hole appears to have been a coastal cave. Christian Georg Andreas Oldendorp, a Moravian missionary, visited the island in the 1760s and observed that the runaways collected fresh rainwater from the many cracks along the rocky terrain of Maroon Ridge, and subsisted primarily on the fruit of Annona murciata, the soursop tree also known as graviola and guanabana. (Norton \& Espenshade 2007: 4)

No archaeological fieldwork has been undertaken on Maroon Ridge. However, two separate teams of archaeologists, one from Denmark and the other from the United States, conducted GIS (Geographical Information Systems) studies in an effort to develop a predictive model of where maroon sites are most likely to be located on Maroon Ridge. The two primary datasets used for analysis were a modern-day topographic map and a detailed survey map taken of the island in 1750 . The variables analyzed included: elevation, slope, viewshed (i.e., which parts of the landscape can be seen from a given location), distance from plantations, roads, and waterways. The Danish model indicated a relative suitability for maroon settlements, and identified three locations on Maroon Ridge with the highest probabilities for settlements to be field tested at a later time (Ejstrud 2008: 10-11). The analysis of the United States-based team aimed at developing a field survey strategy that would yield better results than traditional sub-surface testing methods. They proposed that controlled metal detector survey was the best approach "because a large portion of surviving material culture is metallic" and slave runaways were reported to have machetes, knives, and metal tools (Norton \& Espenshade 2007: 9). Unfortunately, the results of neither GIS studies were tested in archaeological field investigations.

\section{Jamaica}

When the English captured Jamaica from the Spanish in 1655 , they immediately encountered conflicts with the maroons who had run away from Spanish slaveholders. These runaways had established settlements in the mountainous interior and their numbers steadily increased with new runaways from English plantations. As the maroon population grew, colonial officials attempted to defeat them, but were unsuccessful. British troops were brought in and the maroons of Jamaica fought two wars with the British during the 1720s-1730s. With significant deaths on both sides, the maroons made peace with the British in 1739 and signed a treaty granting land and independence to the maroon leader Cudjoe and his troops, in return for ending attacks on plantations and returning any new runaways to slaveholders (Mulcahy 2014: 70-1). The Jamaican maroons have maintained a partial sovereignty from the nation of Jamaica to this day.

Archaeologist E. K. Agorsah pioneered the archaeological study of Jamaican maroons. Born in Ghana, West Africa, Professor Agorsah began his studies on maroons while still at the University of the West Indies in Mona, Jamaica. This island received a high percentage of enslaved Africans from the Gold Coast, most of which lies within present-day Ghana, through the Transatlantic Slave Trade. Agorsah immediately saw similarities between Maroon settlements and rural settlements in Ghana, beginning with the doctoral dissertation he conducted at the University of California As the title of his book, Maroon Heritage: Archaeological, Historical, and Ethnographic Perspectives indicates, he framed his research on maroons using interdisciplinary approaches. His research covered numerous dimensions of maroon life, but two of his findings are particularly significant for archaeological research: first, the most striking similarities between the maroon settlements and Ghanaian rural villages were found in the layout of the villages and the use of domestic space within households; second, and somewhat controversial, concerns his belief that Arawak peoples survived on Jamaica long after the island's English colonization. The traditional narrative for the indigenous presence of Jamaica is that the Spaniards completely decimated the island's indigenous populations long before the English invaded it. Agorsah based his 
interpretation of an Arawak presence in Jamaica during English colonization on the large number of Arawak pottery and implements recovered from Maroon sites. Although it is unclear what this Arawak material culture at maroon sites means, its presence raises questions: Were indigenous peoples a part of the early Maroon communities in Jamaica, as was the case in Hispaniola? Or did they have their own communities, and perhaps, traded with the Maroons? These are tantalizing questions that require additional research.

\section{Cuba}

When the English and French were importing large number of African slaves to labor on plantations in the seventeenth and eighteenth centuries, Cuba had one of the lowest slave populations in the Caribbean. This began to change in the 1790 s and continued well into the 1800s. Between 1800 and 1866, approximately 710,200 African victims disembarked on the island making Cuba a slave society - that is, one dependent on slave labor. With such a large slave population concentrated in areas of the island that produced sugar and coffee, enslaved people frequently ran away.

Just as Agorsah pioneered Maroon archaeology in Jamaica, Gabino La Rosa pioneered archaeological research on slave runaways in Cuba. La Rosa spent almost 40 years studying runaway sites in both eastern and western Cuba, beginning his studies on the eastern long-term palenque sites. They were called palenques because the runaways often built palisades or other defensive structures around their settlements. Runaways in western Cuba, on the other hand, inhabited caves, sometimes for long periods of time. Colonial authorities reported that some very large caves housed as many as 200 to 300 men, women, and children (Singleton 2015: 200).

La Rosa's studies in eastern Cuba focused on reconstructing the settlement's layout, while his cave excavations emphasized analysis of foodways and household possessions. He believes some of the recovered pottery was made by the runaways, but they seem to have purchased pipes and other items from rural stores. Most of the animal food consumed consisted of non-domestic resources, like the hutia (similar to a guinea pig). A somewhat surprising food source recovered from a few sites consist of dog remains, which suggests that the runaways were able to capture and kill the dogs that were used by slave catchers to capture runaways (Corzo 2005: 177).

During slavery, the largest plantations in Cuba were concentrated in Western and Central portions of the island. These areas provide excellent opportunities to study borderland maroons because colonial authorities indicated where they saw runaways. For example, the coffee plantation of Santa Ana de Biajacas, where I conducted archaeological investigations, was close to many of the runaway sites La Rosa excavated (Singleton 2015). The plantation was also near many of the places where colonial authorities reported sightings of runways. These runaways formed small groups of 15 to 20 individuals and stayed at large indefinitely, coming together to raid plantations and dispersing into smaller groups at night for shelter. It may be difficult to identify this form of marronage from archaeology alone, but runaways of this type possibly occupied some of the cave refuge sites that archaeologists have identified and excavated in Cuba and other islands.

\section{Hispaniola}

African slavery and marronage in the Americas began in Hispaniola when in 1501 an enslaved person of African descent, most likely a Ladino (a person of African descent which was knowledgeable in Iberian languages and culture), was reported to have runaway to where the native population lived (Deive 1997: 19-20). Although the first Africans introduced to Hispaniola came from the Iberian Peninsula, as early as 1510, African slaves appear to have come directly from Africa. Maroon communities were established shortly thereafter often consisting of Amerindians and Africans, as both groups were forced to labor in mining and sugar mills. 
My study of marronage begins with the first African slave revolt in 1522 because its survivors are known to have established long-term runaway settlements, some of which persisted throughout the eighteenth century. The revolt began at Isbela, the sugar plantation of Diego Columbus (son of Christopher Columbus), about $15 \mathrm{~km}$ north of the city of Santo Domingo (FIGURE 3). From there the slave rebels went to an hato (cattle ranch), and then to another sugar plantation. They were finally stopped by colonial authorities at the original town of Azua (identified in FIGURE 3 as Old Azua), approximately $110 \mathrm{~km}$ from where the slave revolt began. Most of the runaways survived the attack, and fled to the mountains west of Azua, known as the Bahoruco Sierras. This was close to the border of presentday Haiti. Others possibly fled eastward to the hills and mountains around the present-day town of San José de Ocoa (Read 1986: 22). In both places, they established long-term settlements known as manieles. The word maniel appears to have originated from the Taino, an indigenous, precolonial people of Hispaniola. Bartolomé de las Casas (1967: 43), the great defender of Amerindians throughout Colonial Spanish America, described a Taino province named Maniey that contained high mountains with valleys, rivers, beautiful waterfalls, very fertile land with abundant natural fruits. In fact, Maniey's location coincides with the runaway settlements that became known as El Maniel de Ocoa (Vega 1990: 27, 79 shown on Mapa 4) discussed in the remainder of this essay. At some point the term "maniel" became associated with slave runaway settlements of both Amerindian and Africans, but only in the Dominican Republic (Deive 1980: 432).

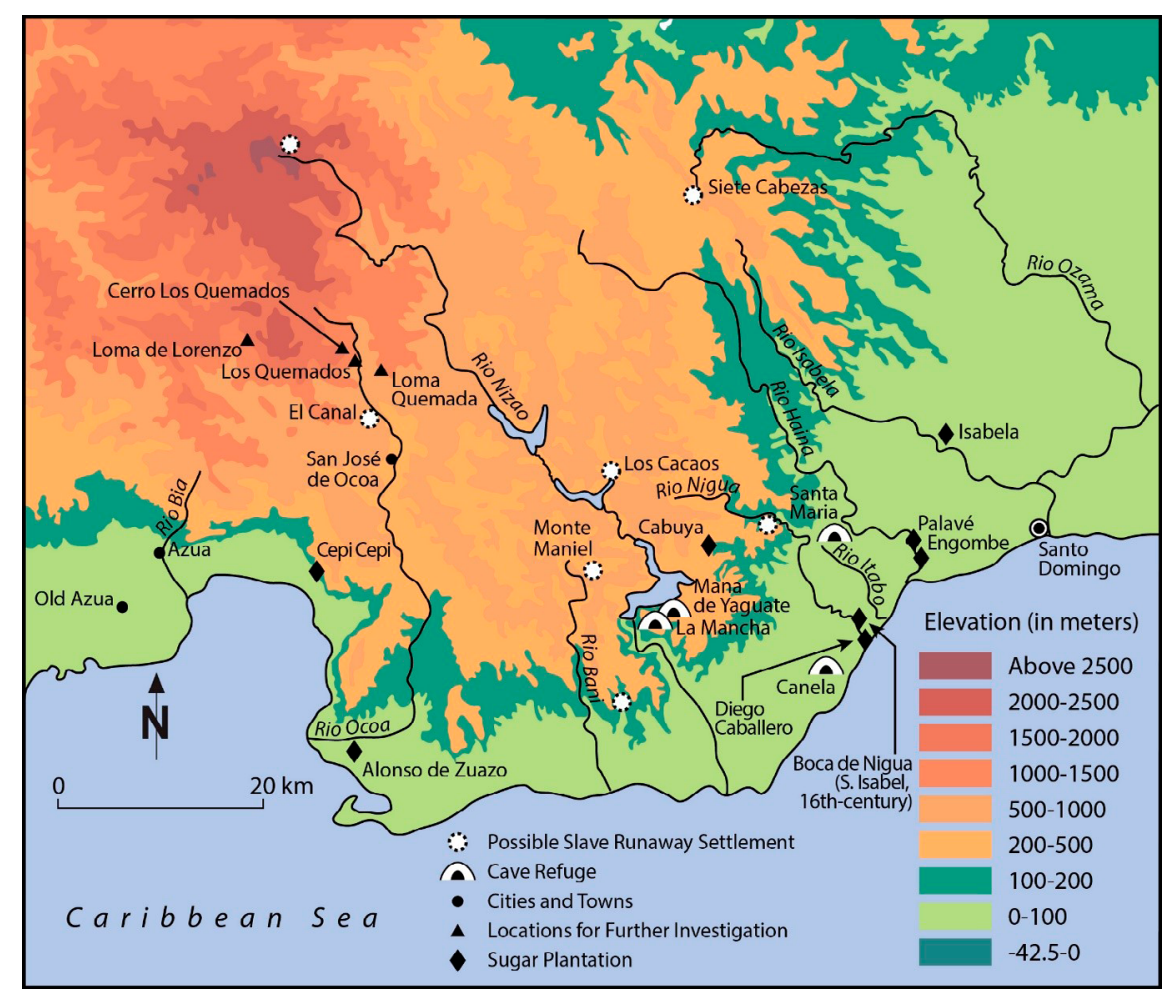

Fig. 3. Map of Project Area illustrating runaway settlements (manieles) and cave sites showing distances from plantations and towns.

Source: Instituto Geografico Universitario - Universidad Autónoma de Santo Domingo (2000). República Dominicana Mapa Físico. Redrawn to emphasize project area by Syracuse University Cartographic Laboratory. 
My study focuses on locating slave runaway sites east of Azua, as the agricultural enterprises that utilized slave labor were concentrated in this area, particularly near or alongside the rivers. At this stage, the research can be described as a mapping project and a prelude to archaeological field investigation. The objectives include: (1) collection of data on the location, distribution, and proximity of slave runaway settlements to plantations, cities and towns, arable soils, and non-domestic food resources from written sources, cartographic sources, previous archaeological research in an effort to locate slave runaway sites; (2) evaluation of the self-sufficiency of these settlements based on their location and the extent to which these communities relied on the outside world for their survival; (3) testing and refinement of Diouf's spatial concepts of borderland and hinterland marronage for archaeological investigation; (4) analysis of the relationships between the two broad categories of runaway sites-temporary refuge sites (usually caves) and long-term settlements (manieles)-to understand how runaways used the landscape.

At this stage of the research, the project team has begun locating sites based on previous research, documentary sources, and oral interviews. We also visited six cave sites and two potential manieles: Los Cacaos and El Canal (FIGURE 3) and located eight plantations. As shown on Figure 3, most manieles are located above or very close to the headwaters (cabeceras) of the rivers, and their tributaries. The location of runaway settlements near the headwaters of rivers was characteristic of maroon communities in other places of the Americas as well.

In Cuba, Corzo (2003: 240-1) found a maroon settlement located near the headwaters of the Calunga stream and named it Calunga after the river. In Minas Gerais, Brazil, a mid-eighteenthcentury map depicts about 27 quilombos along the headwaters of rivers and tributaries (Luis Symanski, pers. communication, 2019). In a similar vein, the maroons of Suriname established their settlements along the major rivers, although not necessarily at the headwaters. Additionally, the Saramaca, a confederation of Suriname maroons, took the name of the river to identify themselves.
Our primary objective, however, was to locate sites associated with El Maniel de Ocoa, one of three major concentrated areas of slave runaway settlements in the southwestern Dominican Republic. Fray Cipriano de Utrera noted that one zone of these manieles was located "in the mountains where the Ocoa River flows" (Read 1992: 36). According to the Archbishop Francisco de la Cueva Maldonado, the maniel consisted of four settlements with 600 families and more than 1,000 occupants in total (Read 1986: 21). Although it is unclear when El Maniel de Ocoa was established, a military operation destroyed it by arson in 1666. Colonial officials justified its destruction as necessary to curtail the spread of various epidemics ravaging the island (Read 1986: 32), but the fire also suppressed and displaced the maniel's remaining occupants.

One particularly helpful source for locating these settlements is David Dixon Porter's diary (1978). Porter was a naval officer of the United States navy who served in the Mexican War (1846-1848) and US Civil War. In 1846, prior to the Mexican War, US President James Polk sent Dixon on a mission to the newly independent Republic of Santo Domingo (Dominican Republic) because the nation's officials had requested recognition from the United States and protection against attacks from its neighbor, the Republic of Haiti. Porter's assignment was to report on the social, economic, political, and military conditions in the Dominican Republic, as well as assess the benefits a relationship with the Dominican Republic would provide the United States.

During his four-month trip, Porter spent a great deal of time in and around Ocoa. He described the area, often providing details of some places and how far he had traveled from one location to another. He apparently visited areas associated with El Maniel de Ocoa and was taken to these places by descendants and new waves of slave runaways who had reoccupied them, and perhaps, memorialized them as part of El Maniel de Ocoa. Although Porter visited the area 180 years after the alleged destruction of El Maniel de Ocoa, it was still referred to as El Maniel during his time 
(Porter 2014). At the moment, I am tracing his journey through the area very carefully to precisely identify which places he visited. For example, three locations in this area are known as Quemados [burnt], which suggest that these areas may have been burned by the Spanish troops. Porter described the Quemados as a very rugged area to travel through for both him and his horses. This rugged terrain, however, may have made the area the perfect location for runaway slave settlements.

Few artifacts have been reported from maroon sites in the Dominican Republic with the exception of the José Leta site located in the southeastern part of the Dominican Republic (Arrom \& Arévalo 1986). Scarcity of artifacts seems characteristic for many slave runaway sites including those long-term settlements that occurred throughout the Americas. Unless the slave runaways established trade relationships with rural shopkeepers or enslaved laborers, their access to goods was limited to what they made for themselves or raided from plantations. Two artifacts diagnostic of slave runaway presence were recovered from caves in Bahoruco. One is a fotuto - a flute-like device - made from a conch shell (Vega 1979: 18) primarily associated with the indigenous peoples in many parts of the Americas (FIGURE 4). Slave runaways appropriated fotutus, and appear to have used them for communication, perhaps to warn others of impending dangers such as a troop of slave catchers. The other artifact is a fragment of an iron chain, either part of arm or leg irons used to restrain enslaved individuals. Leg irons and chains were found at cave refuge site in Cuba (Hernández, Rodríguez \& Antúnez 2012: 101-2), indicating that despite being shackled, some enslaved individuals successfully ran away.

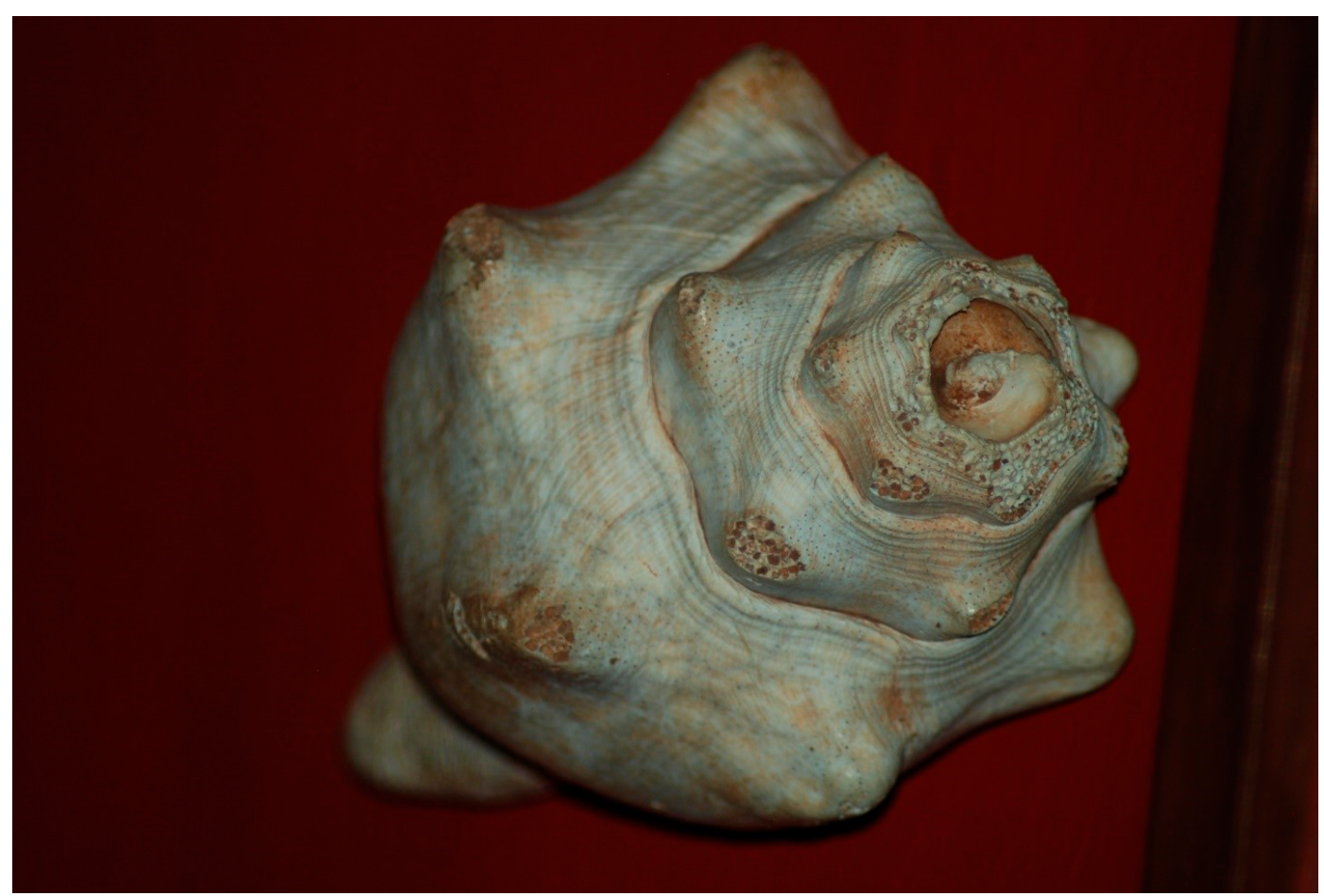

Fig. 4. Fotutu made from Conch Shell. Exhibit Display at Museo del Hombre Dominicano, Santo Domingo, Dominican Republic.

Source: Victor Camilo Bencosme. 


\section{Conclusion}

Marronage shared many similarities throughout the Caribbean, but the opportunities and frequency of marronage varied from island to island. Location, size, topography, ecology, cultural and political contexts certainly impacted the many ways enslaved people chose to flee from enslavement. The archaeological study of marronage presents many challenges for archaeological research because the sites are difficult to find, are often inaccessible, and yield few, if any, artifacts. Thus, the process of identifying, locating, and recording maroon sites is fraught with uncertainty. Yet, maroon sites are so important for understanding slave flight, survival, and resistance that they should not be ignored. Moreover, marronage is the best form of overt slave resistance that archaeologists can investigate. While slave revolts are the clearest evidence of slave resistance, they are fleeting occurrences that leave few archaeological traces.
Archaeologists can best study slave revolts by focusing on their material effects, that is, the material conditions or spatial practices put in place after a revolt occurred. For example, the construction of walls, gates, watchtowers, and other architectural features to control movement and intimidate enslaved people when they were outside of the areas designated for them. These architectural features comprised the material effects of resistance that not only indicate elite reactions to resistance but also provide insights into how Afro-descendants manipulated these material effects to their advantage.

Archaeological study of marronage, in turn, provides insights into material strategies runaways deployed to survive, and in many cases their self-liberation was short-lived. To comprehend slavery, it is important to understand how it was resisted. As the archaeological study of slavery expands, our efforts to investigate marronage should also do the same.

SINGLETON, T.A. Arqueologia da marronagem nas Antilhas do Caribe. R. Museu Arq. Etn., 35 01-13, 2020.

Resumo: $O$ estudo arqueológico de maroons nas Antilhas do Caribe apresenta oportunidades e desafios. Em pequenas ilhas, os fugitivos tinham poucos lugares onde podiam buscar refúgio da escravidão e iludir a captura por longos períodos de tempo. Consequentemente, esses sítios foram ocupados brevemente e têm sido difíceis de localizar e identificar. As Grandes Antilhas (Cuba, Jamaica, Hispaniola e Porto Rico) possuíam locais de refúgio de curto prazo e assentamentos de longo prazo comparáveis aos quilombos. Os arqueólogos foram mais bem-sucedidos em suas investigações de maroons em Cuba e na Jamaica. Em Hispaniola, onde estou trabalhando no momento, apenas alguns locais de cavernas e um suposto maniel (o termo local para um assentamento maroon de longo prazo) foram estudados. Neste artigo, forneço uma visão geral do estudo arqueológico de marrons nas Ilhas do Caribe e minha pesquisa preliminar para localizar El Maniel de Ocoa, um importante assentamento de fugitivos de escravos por mais de cem anos, entre 1500 e 1660.

Palavras-chave: Escravidão, Marronagem, Arqueologia Histórica, Arqueologia do Caribe, Resistência 


\section{Bibliographic references}

Agorsah, E.K. (Ed.). 2000. Maroon Heritage: Archaeological, Historical, and Ethnographic Perspectives. University Press of West Indies, Mona, Jamaica.

Arrom, J. J.; Arévalo, M.A.G. 1986. Cimarrón. Fundación García-Arévalo, Santo Domingo, República Dominicana.

Armstrong, D.V. 2015. Cave of Iron and Resistance: A Preliminary Examination. Barbados Museum and Historical Society 61: 178-199.

Corzo, G.R. 2003. Runaway Slave Settlements in Cuba: Resistance and Repression. Translated by Mary Todd. University of North Carolina Press, Chapel Hill, USA.

Corzo, G.R. 2005. Subsistence of Cimarrones: An Archaeological Study. In: Dawdy, S.L.; Curet, A. L.; Corzo, G.R. (Ed.). Dialogues in Cuban Archaeology. University of Alabama Press, Tuscaloosa, 163-180.

De Las Casas, B. 1967. Apologética Historia Sumaria. vol. 1. Instituto de Investigaciones Históricas, Universidad Nacional Autónoma de México, Ciudad de México.

Dator, J. 2014. Frank Travels: Space, Power, and Slave Mobility in the British Leeward Islands, c. 1700-1730. Slavery and Abolition 36: 335-359.

Deive, C.E. 1980. La Esclavitud Del Negro En Santo Domingo (1492-1844). vol. II. Museo del Hombre Dominicano, Santo Domingo, República Dominicana.

Deive, C.E. 1997. Los Guerrilleros Negros: Esclavos fugitivos y cimarrones en Santo Domingo. Fundación Cultural Dominicana, Santo Domingo, República Dominicana.

Diouf, S. A. 2014. Slavery's Exiles: The Story of the American Maroons. New York University Press, New York.
Ejstrud, B. 2008. Maroons and Landscapes. Journal of Caribbean Archaeology 8: 1-14.

Handler, J.S. 1997. Escaping Slavery in a Caribbean Plantation Society: Marronage in Barbados, 1650s-1830s. The New West Indian Guide/Nieuwe West-lndische Gidx 71: 183-225.

Hernández, O.L.; Rodríguez, B.T.; Antúnez, C.A. 2012. Esclavos y cimarrones en Cuba: Arqueología Histórica en la cueva el Grillette. Centro de Investigaciones Precolombinas, Instituto Superior del Profesorado Dr. Joaquín V. González, Buenos Aires.

Mulcahy, M. 2014. Hubs of Empire: The Southeastern Lowcountry and the British Caribbean, Regional Perspectives of Early America. John Hopkins University Press, Baltimore, USA.

Newman, S.P. 2017. Rethinking runaways in the British Atlantic World: Britain, the Caribbean, West Africa and North America. Slavery and Abolition 38: 49-75.

Norton, H.K.; Espenshade C.T. 2007. The Challenge in locating maroon refuge sites at maroon ridge, St. Croix. Journal of Caribbean Archaeology 7: 1-17.

Perdikaris, S. et al. 2013. The Caves of Barbuda's Eastern Coast: Long term occupation, Ethnohistory, and Ritual. Caribbean Connections 3: 1-9.

Porter, D.D. 1978. Diario de una misión secreta a Santo Domingo (1846). Editora de Santo Domingo, Santo Domingo, República Dominicana.

Porter, D.D. 2014. Diario de una misión secreta a Santa Domingo (1846): Reporte de El Maniel. Fundacíon Ocoa de Pie, Santo Domingo, República Dominicana.

Read, A. 1992. Apuntes para una Historia de los orígenes de San José de Ocoa. Asociación para el 
Desarrollo de San José de Ocoa (ADESJO), San José de Ocoa, República Dominicana.

Read, M.A.O. 1986. Cimarron, Maniel, y Ocoa. Alfa \& Omega, Santo Domingo, República Dominicana.

Reilly, M.C. 2019. Archaeology Below the Cliff: Race, Class, and Redlegs in Barbadian Sugar Society. University of Alabama Press, Tuscaloosa, USA.

Ritz, T. 2016. Marronage Unbound: Colonial Governance and Maroon Resistance to Enslavement in the French Caribbean. PhD. Syracuse University, Syracuse, USA.
Singleton, T.A. 2015. Slavery Behind the Wall: An Archaeology of a Cuban Coffee Plantation. University Press of Florida, Gainesville, USA.

Smith, F.H. 2008. The Archaeology of Alcohol and Drinking. University Press of Florida, Gainsville, USA.

Vega, B. 1979. Arqueología de los Cimarrones del Maniel del Bahoruco. Boletín del Museo del Hombre Dominicano 12: 11-48.

Vega, B. 1990. Los Cacicazgos de la Hispaniola. Fundación Cultural Dominicana, Santo Domingo, República Dominicana. 